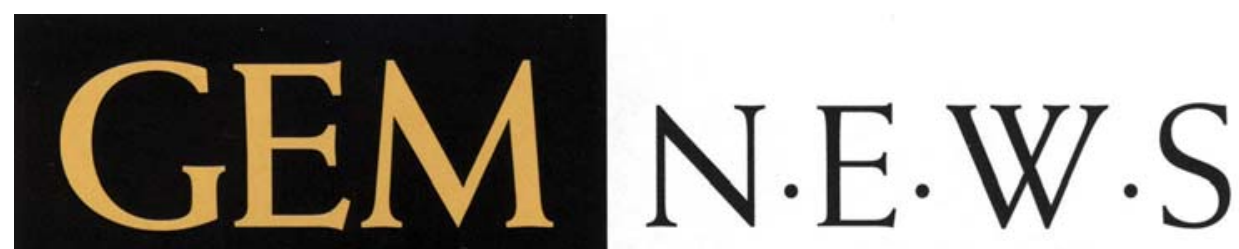

Editors - Mary L. Johnson, John I. Koivula,

Shane F. McClure, and Dino DeGhionno

GIA Gem Trade Laboratory, Carlsbad, California

Contributing Editors

Emmanuel Fritsch, IMN, University of Nantes, France

Henry A. Hänni, SSEF, Basel, Switzerland

Karl Schmetzer, Petershausen, Germany

\title{
TUCSON 2000
}

The kaleidoscope of gems that is Tucson showed many more colors this year than we have seen for some time, and most of the shows were far more successful than in previous years. Although it is impossible to report the full range of items seen by the Gem News editors and their colleagues, following are some of the new, different, and more plentiful gem materials they encountered.

\section{COLORED STONES AND ORGANIC MATERIALS}

Amphiboles are not necessarily jade. Jonathan and Meagan Passel of Natural Selection, Austin, Texas, showed GIA Gem Trade Laboratory Senior staff gemologist Cheryl

Figure 1. These two cabochons illustrate the range of color of the amphibole rock marketed as "Siberian blue nephrite." The 27.73 ct oval cabochon on the left measures $30.3 \times 16.3 \times 6.5 \mathrm{~mm}$; the 20.12 ct shield on the right measures $30.5 \times$ $17.5 \times 5.2 \mathrm{~mm}$. Courtesy of Natural Selection; photo by Maha Tannous.

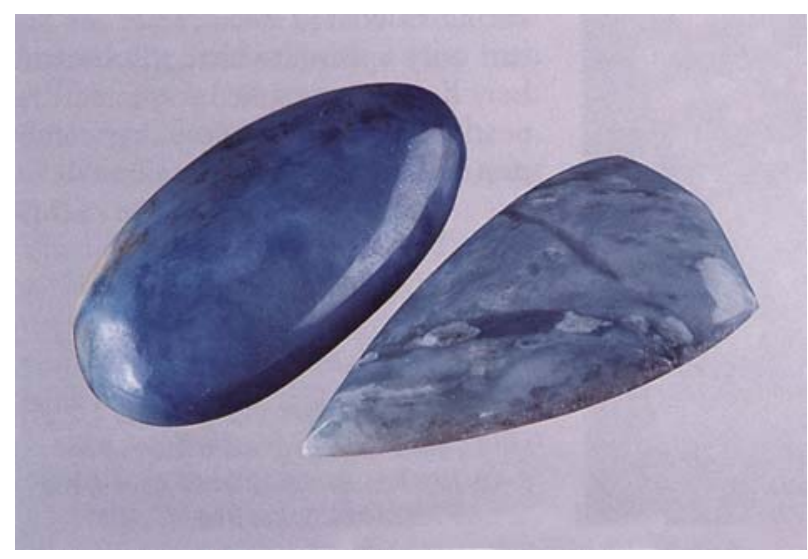

Wentzell and Gem News editor MLJ an amphibole rock marketed as "Siberian blue nephrite" (also called "Dianite" in Russia). The material ranges from mottled saturated "royal" or "lapis" blue to a mottled desaturated grayish blue (figure 1) similar to "denim" lapis (see, e.g., Fall 1993 Gem News, p. 210). First discovered around 1994, this material has been recovered since 1997 as a byproduct of nephrite jade mining in Sakha (formerly Yakutia), central Siberia. Rough is sold as blocks up to $20 \mathrm{~cm}$ across; cabochons typically weigh 15 to $50 \mathrm{ct}$. About 200-300 kg per year of "gem-quality" material is produced.

An electron microprobe analysis of this material, performed at the University of Texas at Austin and summarized in literature provided by the Passels, stated that the rock is composed of a submicroscopic mixture of quartz,

Figure 2. This 59.72 ct tumbled freeform cabochon $(31.8 \times 18.4 \times 12.5 \mathrm{~mm})$ from Nevada is reportedly composed of tremolite/actinolite. Although marketed as "Ghost jade," it lacks the fine-grained, felted structure required to be considered nephrite; hence, it is not a true jade. Photo by Maha Tannous.

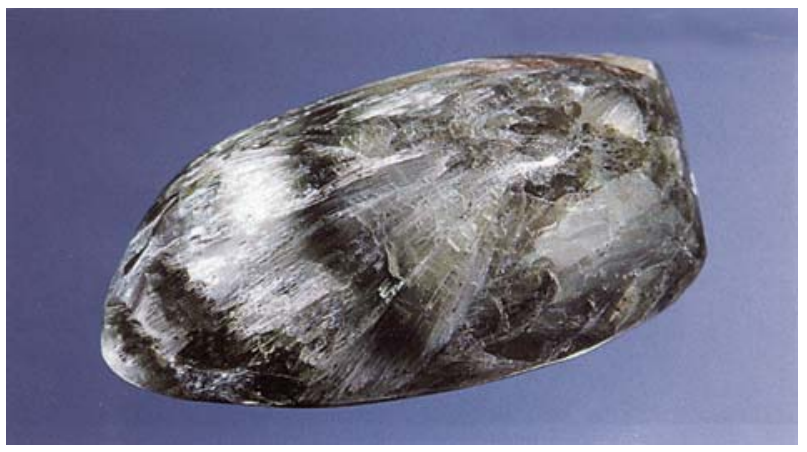




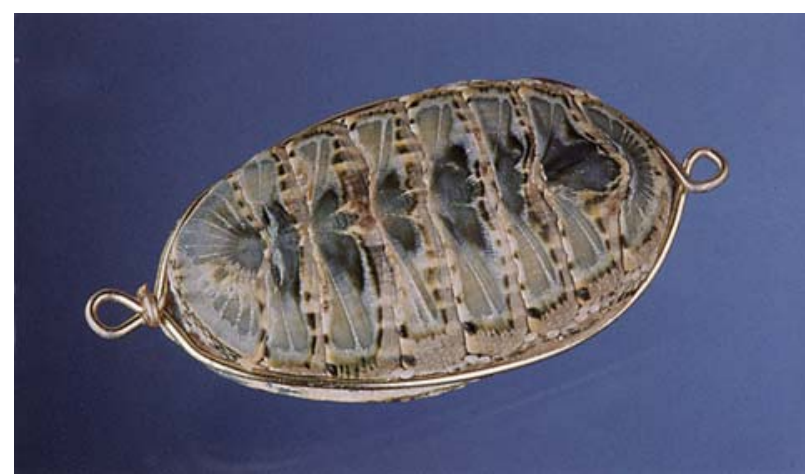

Figure 3. This $36.4 \times 20.8 \times 14.3 \mathrm{~mm}$ blue-gray bead consists of the shells from two chitons that have been polished and attached together. Photo by Maha Tannous.

tremolite, and another (blue) amphibole, potassian magnesio-arfvedsonite. The analysis suggests that nearly all the iron is in the ferric state $\left(\mathrm{Fe}^{3+}\right)$, which is consistent with the fact that the blue color in amphiboles is typically related to $\mathrm{Fe}^{2+}-\mathrm{Fe}^{3+}$ charge transfer (see, e.g., R. G. Burns, 1993, Mineralogical Applications of Crystal Field Theory, 2nd ed., Cambridge University Press, pp. $124-125,197)$. Because the blue rock consists mostly of an amphibole that is distinct from tremolite or actinolite, the GIA Gem Trade Laboratory would not consider it nephrite jade.

A dark green amphibole rock was being marketed as "Ghost jade" by a company of the same name in Yerington, Nevada. This product was introduced in September 1999 at the Denver, Colorado, mineral show. Product literature stated that the material was composed of fibrous tremolite/actinolite grains, has a hardness that can vary from 5 to 7 , and has a density of about 3 . The transparency of individual fibrous amphibole grains (figure 2) caused many of the samples to exhibit sheen and, in some cases, what appeared to be a broad "eye." Company representative Wayne Holland stated that the locality consisted of about seven outcrops in western Nevada, within a 100 mile (about $160 \mathrm{~km}$ ) radius of Yerington. Again, the GIA Gem Trade Laboratory would not call this material nephrite or jade because, although it reportedly has the appropriate mineral composition, the grains do not form a fine-grained, felted aggregate.

Chitons in jewelry. We have seen many creative uses of animal products in jewelry in past years; this year, at the booth of Blue Caribe Gems, Slidell, Louisiana, we saw "beads" made from the polished shells of chitons (figure 3). These marine mollusks have a series of dorsal plates that articulate like the shell of an armadillo. The shells of two chitons from the Caribbean were polished and glued together, then wrapped with a yellow metal wire to form the approximately $3-\mathrm{cm}$-long beads. The delicate blue-gray color of the polished chiton shells was reminiscent of pumpellyite at first glance.
Unusual copal. Many gemologists are fascinated with inclusions in gems. Because of their excellent preservative nature and degree of transparency, amber and other naturally occurring fossil resins can give scientists a clear and intriguing look at past ecosystems in a microcosm. For decades, this editor (JIK) has closely examined both rough and fashioned samples of fossil resin for interesting and unusual inclusions. At Tucson this year, John Medici of Ostrander, Ohio, had a small collection of polished copal resin specimens from Madagascar. While most of the samples appeared to have rather typical inclusions, such as termites, flies, and ants, one piece immediately stood out because it appeared to contain drops of brownish red liquid that were easily visible without magnification (figure 4). Closer examination of this sample with a $10 \times$ loupe revealed that these drops were indeed a somewhat watery liquid of low viscosity, as shown by the presence of free-floating gas bubbles inside some of the largest drops. Since this was the first time such inclusions had been encountered by this editor in a natural resin, the sample was obtained for closer examination.

Several interesting details were revealed with a gemological microscope. As can be seen in figure 5, the appearance of the liquid drops is somewhat reminiscent of blood. It is also interesting to note that the absorption spectrum of the drops as seen through the ocular tube of a gemological microscope (with a small diffraction grating spectroscope used in place of the eyepiece) was similar to that obtained from a human finger when it is illuminated by a strong fiber-optic light source. This spectrum suggests the presence of iron in the copal fluid inclusions, as does the brownish red color of the liquid itself. Also present with the fluid inclusions were two small flies, which appeared to be a type of midge. A relatively large volume of the reddish liquid was observed in the bodies of these insects (see, e.g., figure 6). Because of the relatively fragile nature of copal, as well as the unusual nature of these

Figure 4. This 35.4-mm-long polished rod-shaped piece of copal resin from Madagascar contains eye-visible droplets of a most unusual brownish red liquid. Photo by Maha Tannous.

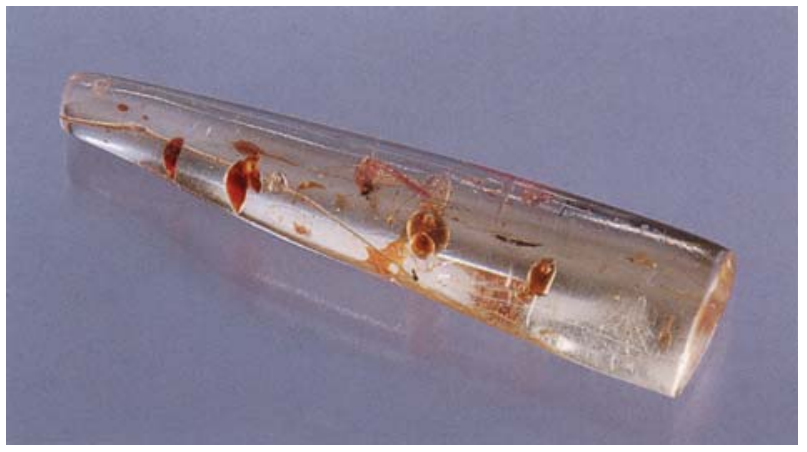




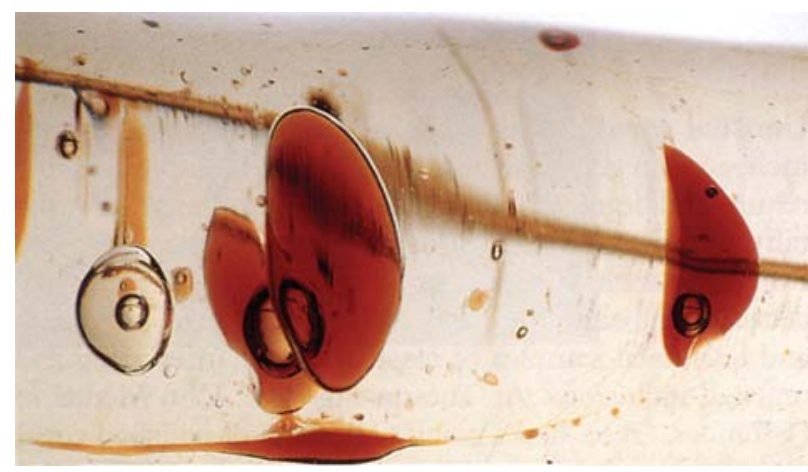

Figure 5. The brownish red fluid droplets trapped in this piece of copal contain mobile gas bubbles. Photomicrograph by John I. Koivula; magnified $10 \times$.

Figure 7. Fine emeralds have been mined recently from the La Pita deposit in Maripi County, Colombia. The emerald crystal occurs with calcite in this $2.5 \mathrm{~cm}$ specimen. Courtesy of Graeber/Himes/Jara; photo by Jeff Scovil.

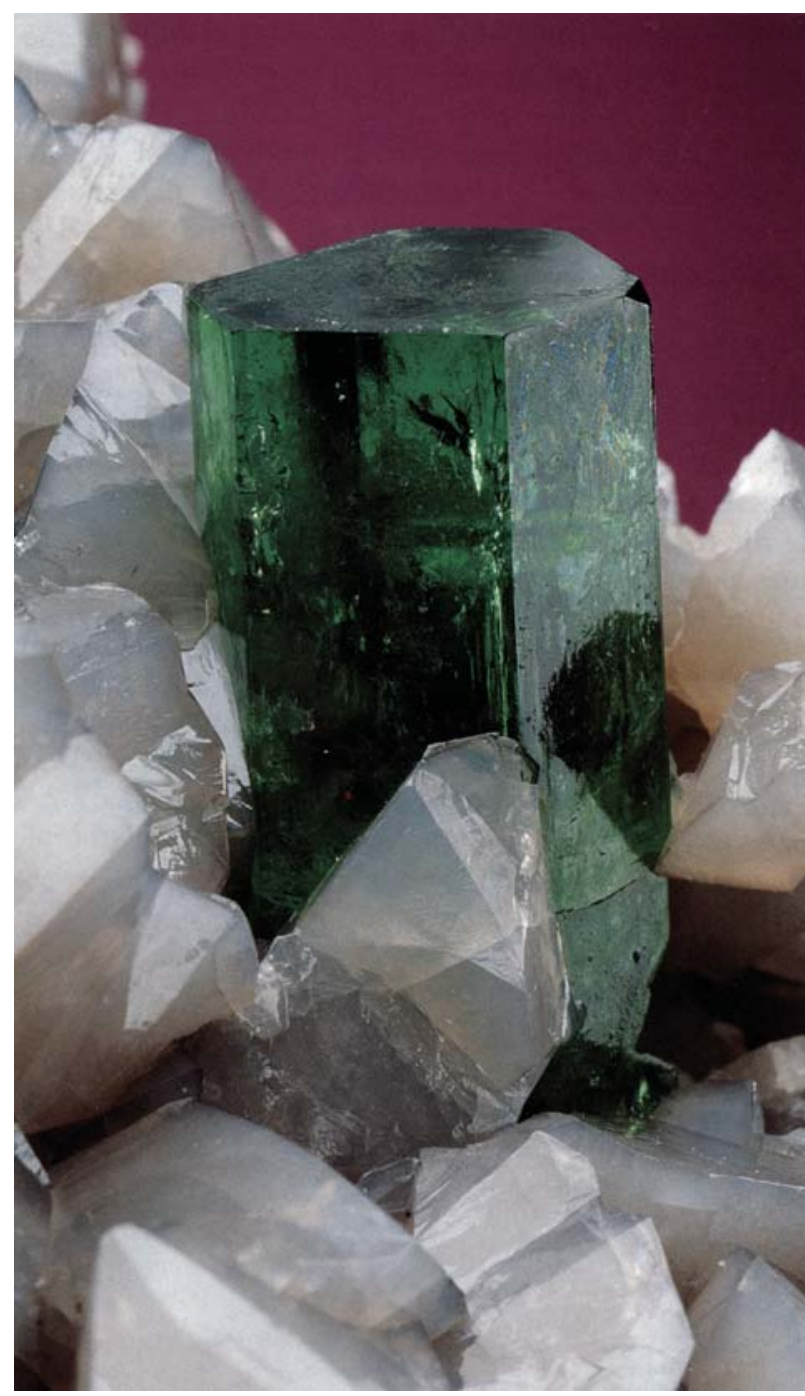

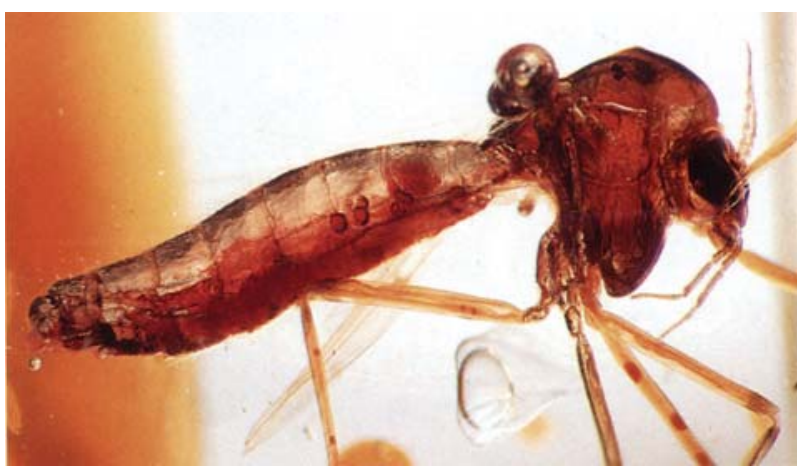

Figure 6. This is one of two small midges that were present as inclusions with the red fluid drops in the copal. Notice the small droplets and areas of red liquid trapped within the body of the midge. Photomicrograph by John I. Koivula; magnified 10×.

inclusions and their rarity, we performed no other form of testing to identify this liquid. If another sample is located with similar inclusions, then perhaps a more complete analysis can be performed by opening some of the voids to obtain liquid test samples.

Newly commercial emerald deposits in Colombia (La Pita and Polveros). According to long-time emerald dealer Gonzalo Jara of Bogotá, Colombia, significant amounts of emeralds are being produced at two deposits in the vicinity of Muzo and Coscuez in the department of Boyacá. The La Pita deposit is in the county of Maripi, near the Coscuez and Peñas Blancas mines. The Polveros deposit is near the town of Muzo, in the county of Muzo (note that the Muzo mine is actually across the county line, in Quipama County).

The La Pita deposit, which first had significant production in 1998-1999 (after four years of management under exploration and exploitation leases), is being mined by the company Prominas both as an open pit and a single tunnel. Mr. Jara described the emeralds from one pocket at La Pita as being very similar to the Peñas Blancas material- "not as yellow as Coscuez, not as blue as Chivor." Finished stones range to more than $40 \mathrm{ct}$. In addition to attractive mineral specimens (figure 7) and facet-quality crystals up to $61 \mathrm{ct}$, some cat's-eye emerald has been found at La Pita.

The Polveros deposit has been known for about 10 years, but it only recently began producing commercial quantities (although the production is less than at La Pita). The mine is an open pit. Many of the emerald crystals there are long and thin (prismatic), like pencils.

There also is new production of emeralds from Alto de la Chula, Chivor, which frequently contain quartz inclusions. "Good" and "fine" material has been recovered since August 1999.

Some new examples of drusy hematite. Drusy gem materials have been popular for some years (see, e.g., Summer 


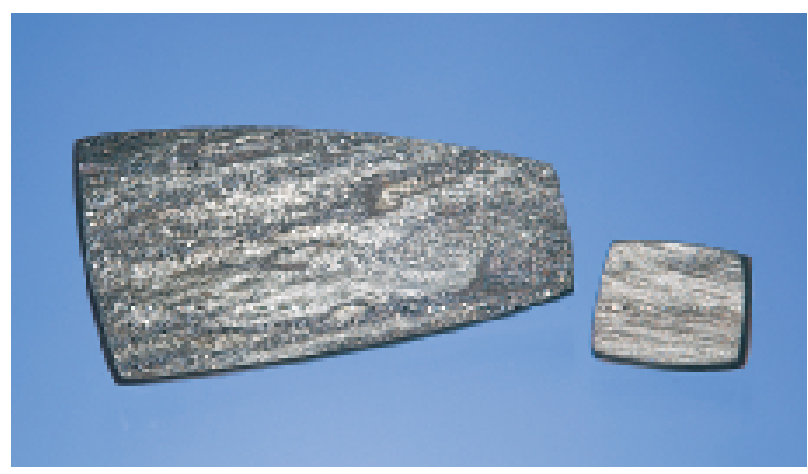

Figure 8. Tablets of specular hematite (left) and drusy hematite (right) from Arizona were among the unusual gem materials seen at Tucson this year. The large piece measures $53.4 \times 28.0 \times 4.3$ $\mathrm{mm}$ and weighs $60.26 \mathrm{ct}$; the smaller sample measures $17.1 \times 14.1 \times 3.3 \mathrm{~mm}$ and weighs $10.77 \mathrm{ct}$. Photo by Maha Tannous.

rials have been popular for some years (see, e.g., Summer 1998 Gem News, pp. 142-143; Spring 1999 Gem News, p. 54). This year at Tucson, we saw hematite cut as drusy in some different ways. Robert Poley of Sweetwater, Prescott, Arizona, sold tablets of specular hematite from the Bradshaw Mountains in Arizona. Most had a velvety surface-similar to "rainbow hematite" without the play of color-but some had larger crystal faces on the surface (both types are shown in figure 8). Bill Heher of Rare Earth Mining Co., Trumbull, Connecticut, had hematite in a different form-"kidney ore," fashioned as clouds (figure 9).

Orbicular jasper from Madagascar. Orbicular jasper from this island nation was showcased as a new gem material at Tucson this year. GIA Gem Trade Laboratory staff members Matt Hall and Dr. Troy Blodgett encountered this material at the booth of Paul Obenich, Madagascar Minerals (madminer@dts.mg). The colors and textures of this jasper are quite diverse: Each of the hundreds of polished samples that were observed showed a multitude of colors (including green, blue, pink, and red; see, e.g., figure 10). However, the abundance of spherical nodules (ranging from approximately $1 \mathrm{~mm}$ to $1 \mathrm{~cm}$ ) is the most prominent feature of the jasper; these spheres also occurred in a variety of colors. Jasper is an opaque, cryptocrystalline quartz; however some of these samples, including the one pictured, contained fine-grained quartz crystals in the interstices between the jasper orbicules. The example illustrated resembles thomsonite from Minnesota in color and shape.

According to literature provided by Mr. Obenich, a mineral prospector sold a few samples of orbicular jasper almost 50 years ago; however, the prospector could not recall the location of the outcrop. Only after methodical searching during two expeditions was the jasper found a

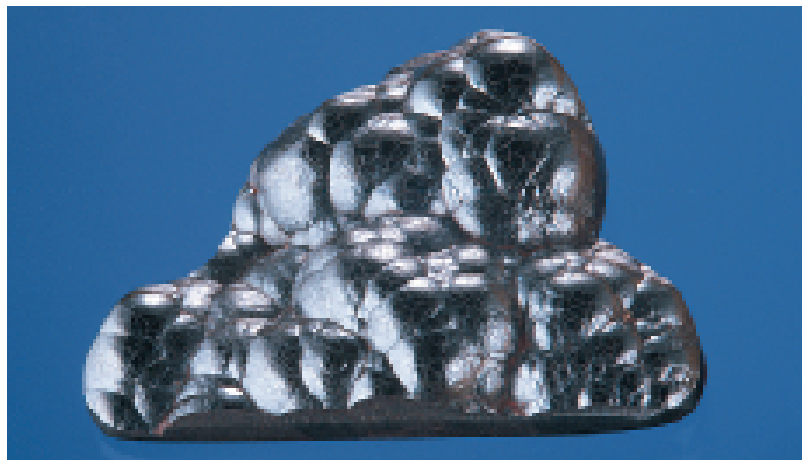

Figure 9. The natural surface of this $43.43 \mathrm{ct}$ piece of "kidney ore" hematite makes an effective representation of a billowing cloud. Courtesy of Rare Earth Mining Co.; photo by Maha Tannous.

few years ago in an approximately $50 \times 30 \mathrm{~m}(170 \times 100$ foot) area on the northwest coast of Madagascar. The locality reportedly is under water most of the time, so mining can occur only at low tide. About 20 tons of the material has been mined so far; it was available at Tucson as polished slabs, tumbled nodules, eggs, and spheres.

Colorful nephrite. Although many vendors at the Tucson shows had nephrite jade of various qualities, we encountered only one dealer, Go Jolly of Myrtle Creek, Oregon, who had nephrite of the type shown in figure 11. The material, which was reportedly from the Fraser River valley in British Columbia, was eye-catching because of the overall quality of the nephrite itself and the bright green inclusions it contained. With magnification, the nephrite appeared to be free of cracks, which indicates that the inclusions had not unduly strained their host. (In general,

Figure 10. Note the pink spheres in this $4.6 \times 3.65$ $\times 2.25 \mathrm{~cm}$ sample of orbicular jasper from Madagascar. Photo by Maha Tannous.

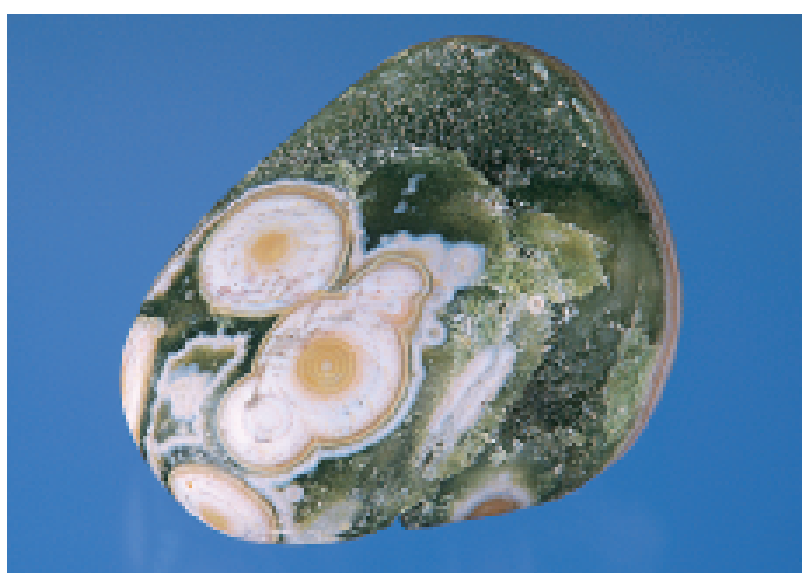




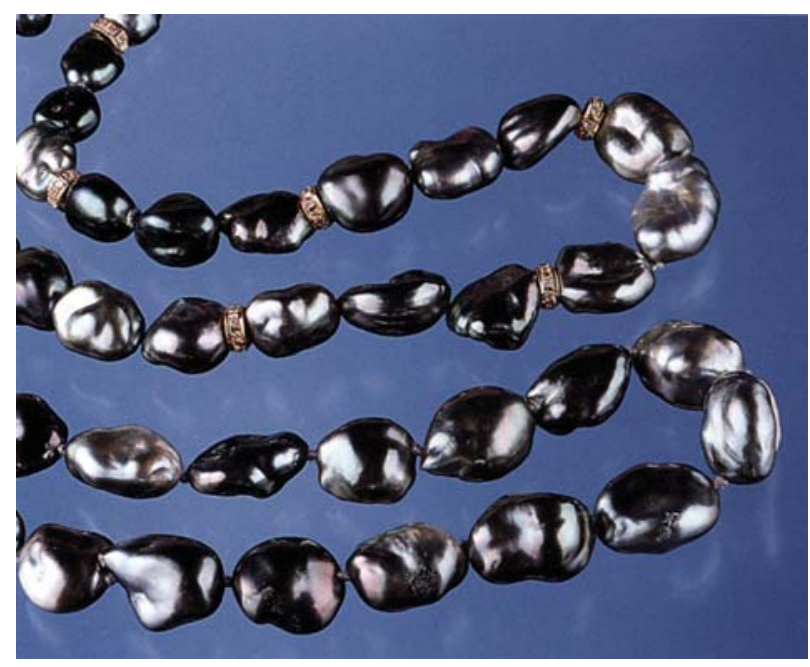

Figure 13. These two necklaces of black Tahitian keshi pearls were created by Michelle Laurenti; the largest keshi is $16.4 \mathrm{~mm}$ in longest dimension. Courtesy of Laurenti and Nesseth, Custom e) Estate Jewels; photo by Maha Tannous.

pyrite "cartouche." The large sample in figure 15 came from Demine Vladislav, Moscow, Russia; the ammonite is from the Ryazan area, near Moscow. The outside of this shell also showed some remnants of iridescent carbonate.

An update on ruby and sapphire from Chimwadzulu Hill, Malawi. The existence of gem-quality corundum on Chimwadzulu Hill in southern Malawi was first reported in 1958 (K. Bloomfield, "The Chimwadzulu Hill ultrabasic body," Transactions of the Geological Society of South Africa, Vol. 61). Chimwadzulu Hill is west-northwest of Ntcheu, approximately $5 \mathrm{~km}$ from the border with Mozambique. The area mined is on the summit of the hill, at an altitude of about $1,525 \mathrm{~m}$. The eluvial deposits have been worked sporadically since the early 1960s. Early mining efforts recovered mainly sapphire, which was predominantly in blue, green, and yellow hues. Most of the sapphires were not highly saturated, and therefore required heat treatment.

In the 1980s, mining was conducted-with German technical assistance-by a quasi-government organization known as the Malawi Development Corp. Workings were concentrated on the crown of the hill, with some good-quality ruby recovered from one area, but with no discernible continuity or trend in the mineralization. The large quantities of sapphire that entered the market from other locations throughout the world eventually rendered this operation uneconomic, and mining was terminated in 1986. Heavy industry was largely discouraged during the Presidency of Hastings Banda (1964-1994), and no further attempts at organized mining were made in the eight years following mine closure.

In September 1994, Mineral Exploration Pvt. Ltd.

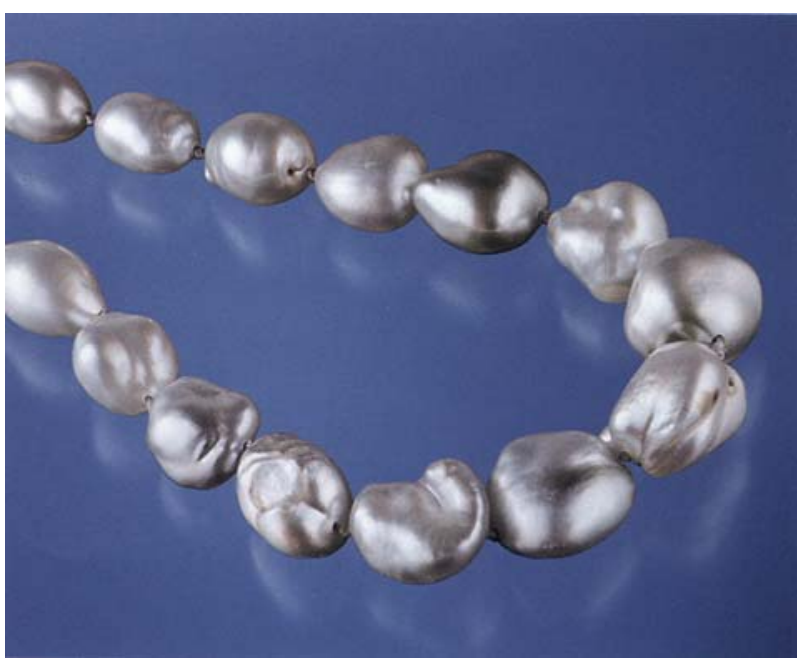

Figure 14. The grayish white keshi pearls in this necklace (largest, $18.2 \mathrm{~mm}$ ) by Michelle Laurenti formed in Tahitian Pinctada margaritifera oysters, which usually produce black cultured pearls. Courtesy of Laurenti and Nesseth, Custom et Estate Jewels; photo by Maha Tannous.

Figure 15. This large $(59.1 \times 27.8 \times 16.7 \mathrm{~mm})$ "cartouche" shape is a Russian pyritized ammonite sliced across the shell. Photo by Maha Tannous.

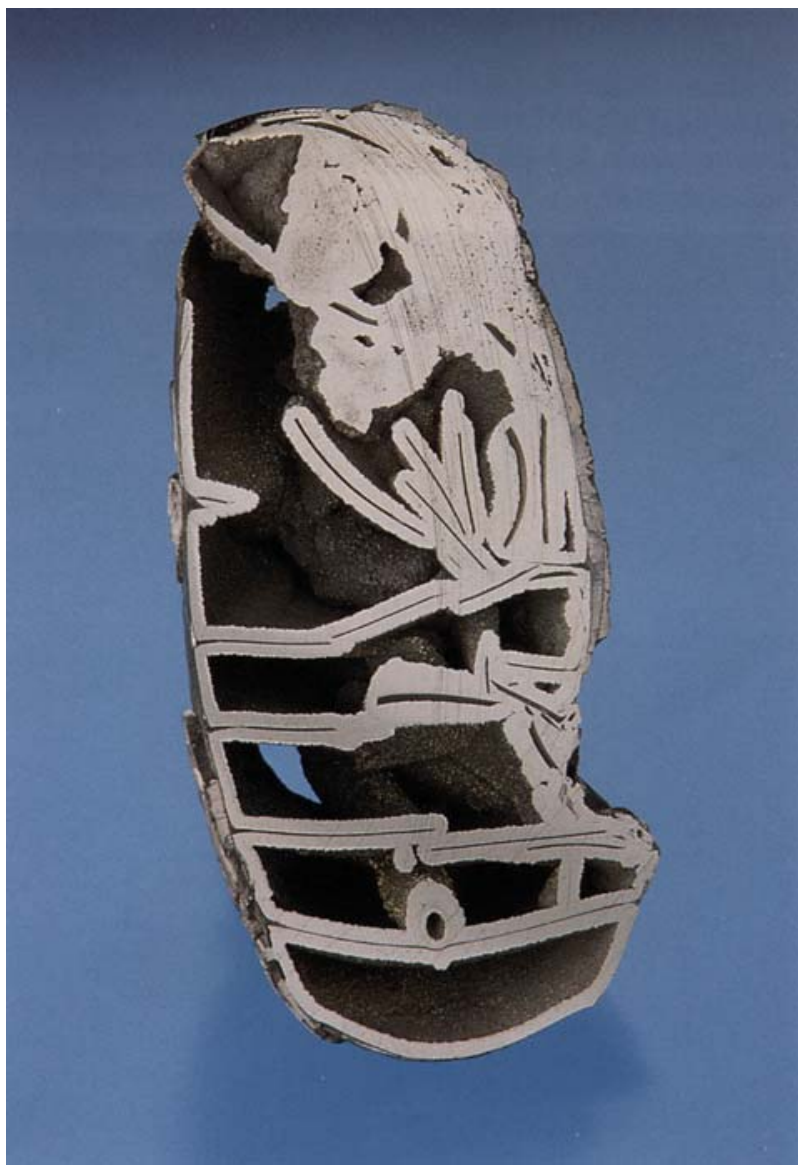




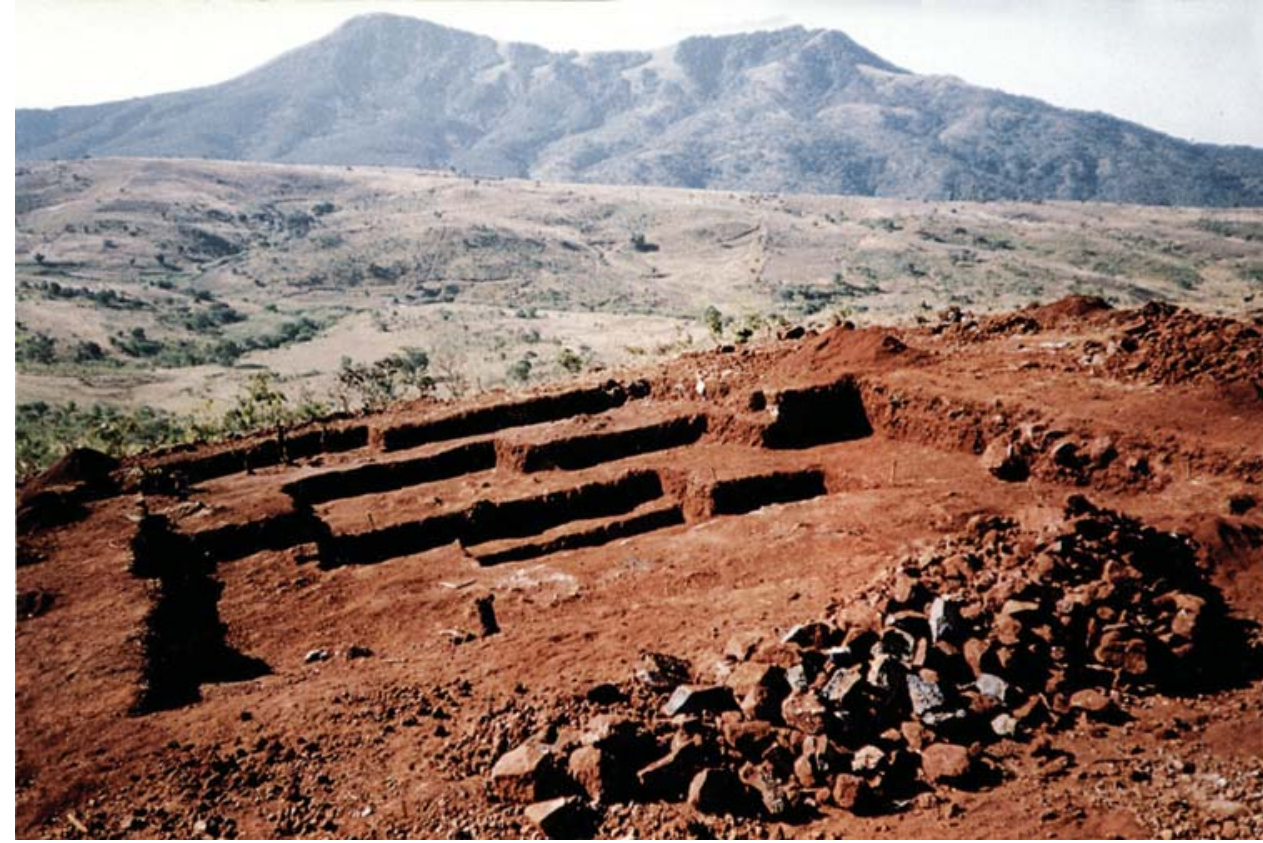

Figure 16. This is a typical ruby production pit on Chimwadzulu Hill in southern Malawi. The view looks north to Donza Mountain. Photo (C) David Hargreaves.

(Minex) was granted a license to mine on Chimwadzulu Hill and to explore contiguous areas. Willard International, a Panamanian company with head offices in London, is the mine operator and $85 \%$ owner of Minex. Geologic exploration and limited mining efforts initiated late in 1995 resulted in the recovery of an estimated 100+ $\mathrm{kg}$ of sapphire similar to that described above; rubies were found occasionally, but there was still no identifi-

Figure 17. This 2.27 ct ruby was faceted from Chimwadzulu Hill material. Photo (C) GIA and Tino Hammid.

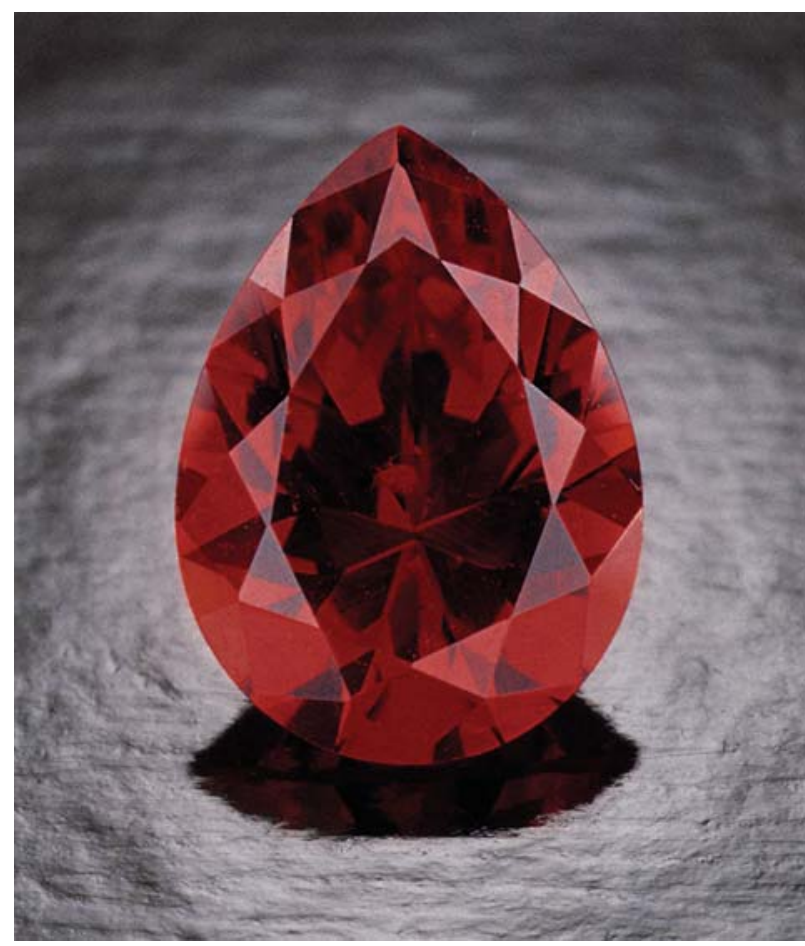

able trend to their recovery. However, the subsequent digging of test pits led to the discovery of a significant ruby trend in mid-1997.

Chimwadzulu Hill is composed of an ultramafic body that is hosted by metasedimentary rocks (i.e., gneisses and schists; see the Bloomfield reference cited above, and K. Bloomfield and M. S. Garson, 1965, The Geology of the Kirk Range-Lisungwe Valley Area, published by The Government Printer, Zomba, Malawi). The intrusive was subsequently metamorphosed, resulting in the formation of serpentinized peridotite and amphibolite. It dips northeast, and has a surface exposure of about $1 \mathrm{~km}$ in diameter. Over much of Chimwadzulu Hill, the bedrock has been deeply weathered and altered to an aggregate of deep red, friable, ironrich, porous clay. In various places, the weathered bedrock is overlain by this residual soil. Corundum is recovered from these soils-particularly where this gem mineral is abundant in the underlying bedrock-and from the weathered bedrock itself.

The systematic test pits revealed that the majority of the chromium-bearing corundum (ruby or orange, pink, or purple sapphire) is localized within areas of weathered bedrock that are usually $20 \mathrm{~m}$ or less in lateral extent (figure 16). Approximately 100 of these potential mining targets have been tentatively identified. In limited portions of these "hot spots," concentrations of chromiumbearing corundum can be very high; one pit $2 \times 2 \times 2 \mathrm{~m}$ yielded $7.6 \mathrm{~kg}$ of corundum. Mining of the present site on Chimwadzulu Hill is continuing, as is exploration of other corundum occurrences to the north.

The chromium-bearing corundum forms short columnar to tabular hexagonal crystals or crystal fragments. The basal pinacoids (0001) are very well developed, as are the prism faces $(11 \overline{2} 0)$. On some of the more tabular crystals, the rhombohedral face $(10 \overline{1} 1)$ is prominent. Typical dimensions of complete crystals are $1-3 \mathrm{~cm}$ across the basal pinacoid and $0.5-2.0 \mathrm{~cm}$ along the c-axis. Although the crystals generally are significantly fractured, the mate- 


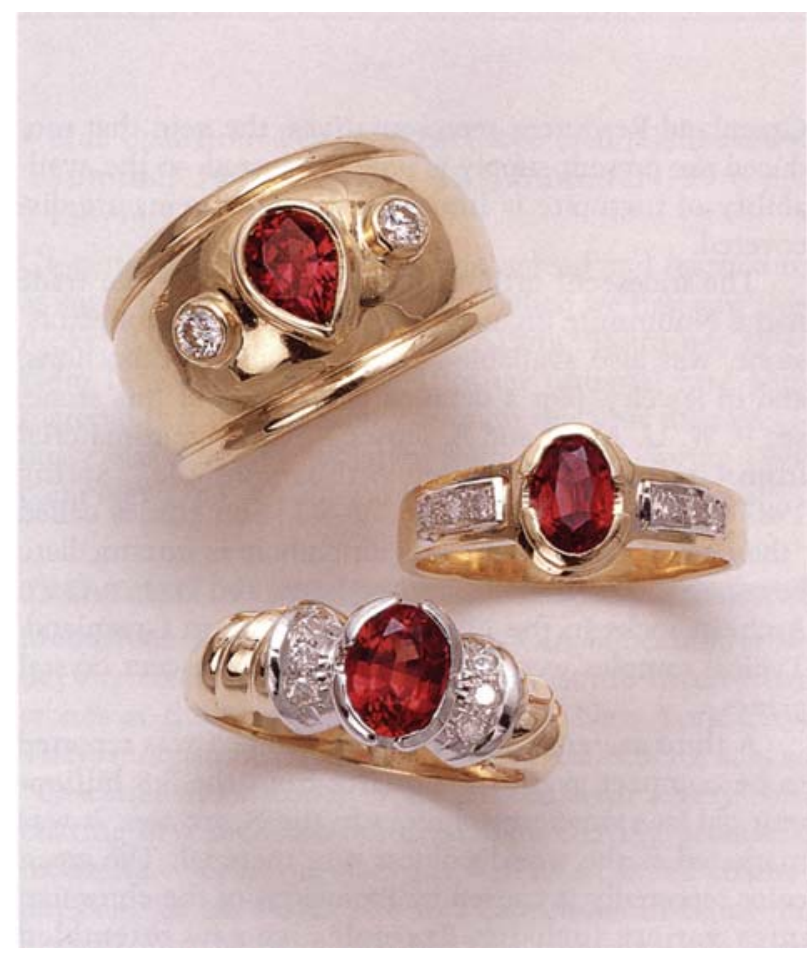

Figure 18. Here, faceted Malawi rubies ranging from 1.4 to 2.1 have been set in fine jewelry. Photo courtesy of The Silurian Co.

rial between fractures is usually of very high clarity. The color of the chromium-bearing corundum ranges from orange through red, to purplish red, almost reminiscent of rhodolite garnet. In terms of tone, recovered material ranges from pale pink through a very deep red. A few crystals exhibit orange and red banding, or orange and purplish red banding, parallel to the basal pinacoid.

According to David Hargreaves of Willard International, approximately $80 \mathrm{~kg}$ of chromium-bearing corundum have been recovered since September 1997. Cutting and marketing of the polished stones is arranged by The Silurian Co. of London. Faceted stones of less than $1 \mathrm{ct}$ are plentiful, and stones of 1-5 ct are not uncommon (figures 17 and 18). A number of very fine gemstones have been cut, the largest of which weighs $16 \mathrm{ct}$. The clarity of these stones renders heat treatment unnecessary.

\section{John L. Emmett \\ Crystal Chemistry \\ Brush Prairie, Washington}

Another locality in Paraíba for cuprian elbaite. Every year at the Tucson Gem and Mineral Show, the Friends of Mineralogy hold a symposium. This year, the symposium theme was Brazilian pegmatites. Editor MLJ attended a talk on "Cuprian elbaite from the Bocheiron Zinho Pegmatite, Paraíba, Brazil," by A. U. Falster, W. B. Simmons, J. W. Nizamoff, and K. L. Webber; Jim Nizamoff presented this talk.

Several pegmatites in Paraíba produce cuprian elbaite (see, e.g., J. Karfunkel and R. R. Wegner, "Paraíba tourmalines: Distribution, mode of occurrence and geologic environment," Canadian Gemmologist, Vol. 17, No. 4, 1996, pp. 99-106). São José da Batalha is the best known, and the only one to date to produce gem-quality material. The latest entry is Bocheiron Zinho No. 2, which is being mined as an open cut, and is a spodumene/lepidolite/elbaite pegmatite; there is a copper/bismuth-sulfiderich layer at the footwall.

Most of the elbaite from Bocheiron Zinho shows a blue radial layer between a pink-to-purplish pink core and a thin green rim; sometimes there is a blue core within the pink core. Quantitative chemical analysis revealed copper evenly distributed throughout the tourmaline - in pink and green as well as blue layers - up to 1.5 wt. $\% \mathrm{Cu}_{2} \mathrm{O}$ (0.25 atoms copper per formula unit). The green layers contain iron, and the pink layers contain manganese. There is up to $25 \%$ vacancy in the $\mathrm{X}$ site (the sodium site) of this tourmaline, but mineralogically it is still elbaite.

Among the inclusions in these tourmalines are: veins of lepidolite replacing tourmaline, copper metal or copper sulfides (as seen in material from São José da Batalha), and bismuth sulfide. The tourmaline itself does not contain a detectable amount of bismuth. So far, the material at Bocheiron Zinho is not gemmy, but gem-quality crystals may someday be found there.

Tugtupite and other gem materials from Greenland. Several GIA staff members talked to Helge Jessen and Jennifer Patterson of Greenland Resources A/S, Copenhagen, Denmark, who were showing many unusual gem materials from Greenland at the GJX show.

Tugtupite (figure 19) was described by A. Jensen and O. V. Petersen in the Summer 1982 Gems «) Gemology

Figure 19. The cabochon (about $2.5 \mathrm{~cm}$ long) in this pendant is cut from the rare gem mineral tugtupite. Courtesy of Greenland Resources A/S; photo by Maha Tannous.

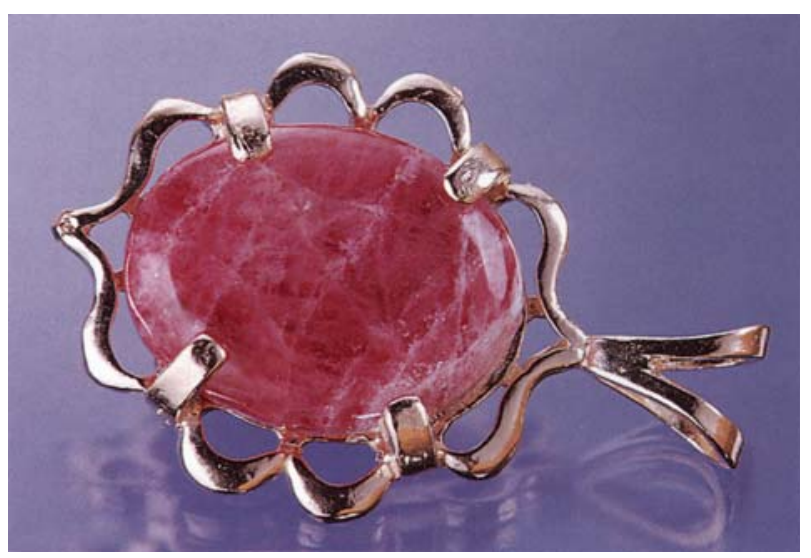




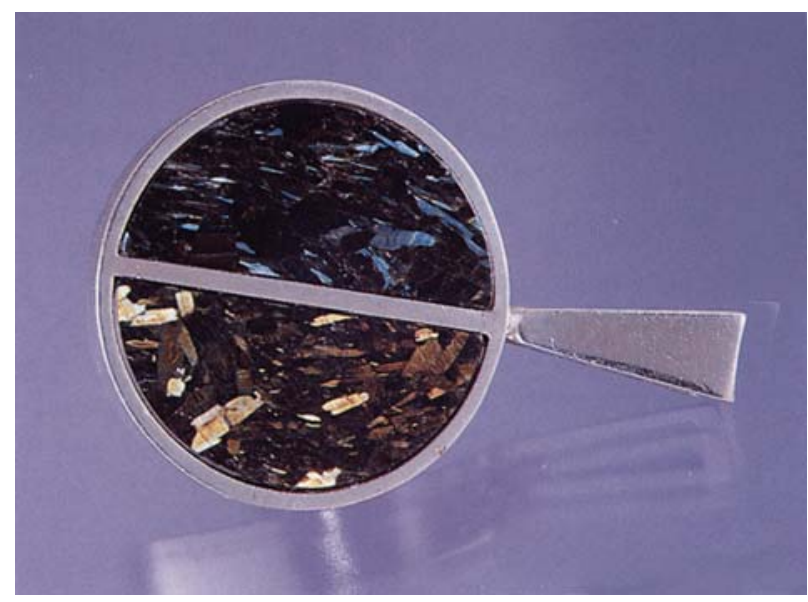

Figure 20. This pendant (about $2 \mathrm{~cm}$ in diameter) contains two half-disks of iridescent orthoamphibole ("Nuummite"). Courtesy of Greenland Resources $A / S$; photo by Maha Tannous.

("Tugtupite: A gemstone from Greenland," pp. 90-94). Formerly sought only by collectors of rare minerals, this unusual gem is now available commercially as cabochons, occasional faceted stones, and gem rough. Pink to red in color, tugtupite is a silicate of sodium, aluminum, beryllium, and chlorine. It fluoresces orange-to-red to long- and short-wave UV radiation. The mineral is found in hydrothermal veins associated with the Proterozoic (late Precambrian) Ilimaussaq alkaline intrusion, near Narsaq in southern Greenland. According to the

Figure 21. This $441.48 \mathrm{ct}$ zircon was faceted from material recently found in the Ilakaka area of Madagascar. Courtesy of Cynthia Renee Co.; photo by Maha Tannous.

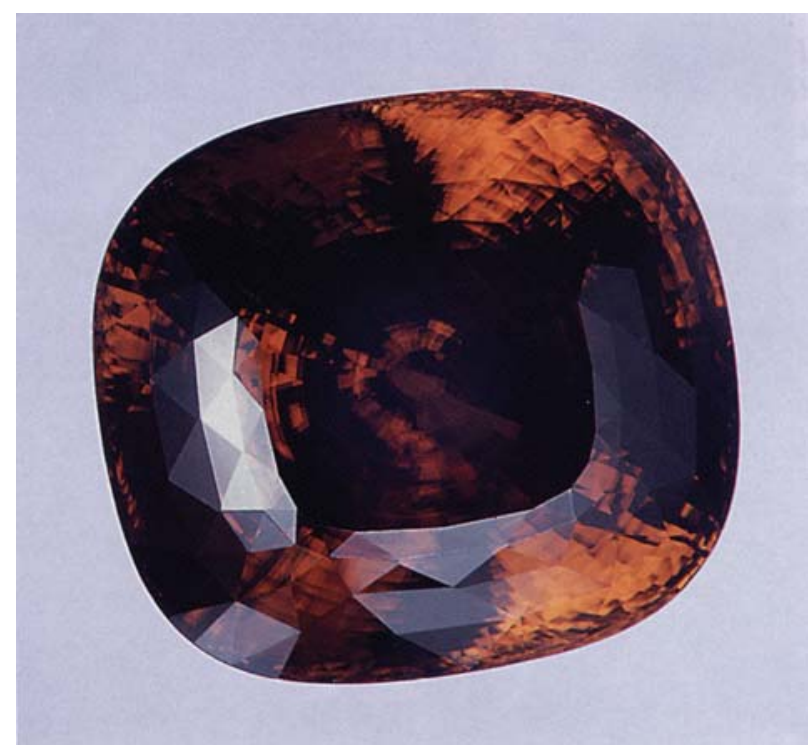

Greenland Resources representatives, the vein that produced the present supply is now exhausted, so the availability of tugtupite is limited until more veins are discovered.

The iridescent orthoamphibole sold under the trade name Nuummite (figure 20), another unusual collectors' stone, was also available-as gem rough, as cabochons, and in jewelry. (For a detailed description of this stone, see P. W. U. Appel and A. Jensen, "A new gem material from Greenland: Iridescent orthoamphibole," Spring 1987 Gems Æ Gemology, pp. 36-42.) Sometimes called "the opal of Greenland," this amphibole is intermediate between anthophyllite and gedrite, and comes from Archean rocks in the Nuuk area of western Greenland. Typical samples were dark green, with iridescent crystal planes.

A third material, sold as "grønlandite," was reported to be compact aventurine quartz from the 3.8 billionyear-old Isua supercrustal rocks in the Nuuk area. It was marketed as the world's oldest gem material. The green color reportedly is caused by inclusions of the chromian mica variety fuchsite. Examples we saw resembled nephrite jade in color, with visual homogeneity. In addition to these materials, we saw ruby in matrix, labradorite, sodalite, pyralspite garnets, and massive yellow prehnite that could easily be mistaken for amber at first glance; all of these were mined in Greenland.

Large faceted zircon. One of the joys of the Tucson shows is seeing gems in unusually large sizes. Staff gemologist Valerie Chabert, from our New York laboratory, noticed a 441.48 ct brown zircon (figure 21) at the booth of Cynthia Renee Co., Fallbrook, California. According to Cynthia Marcusson, the original rough was found in June or July of 1999 at Ilakaka, Madagascar, and weighed about 250 grams. It was subsequently fashioned in Sri Lanka.

Also seen at Tucson. ... Many of the gem materials heralded as new at Tucson this year have been reported in previous issues of Gems $\oplus$ Gemology. For the reader's convenience, following are some of these "new" materials seen at Tucson, with previous Gems «) Gemology references:

- Pink and blue Madagascar sapphires (Summer 1999 Gem News, pp. 149-150)

- Nigerian pink tourmaline and rubellite (Winter 1998 Gem News, pp. 298-2991

- Spessartine, from Brazil, Nigeria, and Zambia in particular (most recently in Spring and Winter 1999 Gem News, pp. 55, 216, and 217, respectively)

- Abundant multicolored sunstone from Oregon (Summer 1997 Gem News, p. 145)

- Widely available Russian demantoid garnets, many showing classic horsetail inclusions (see, e.g., Mattice et al., Fall 1999 Gems Æ) Gemology, pp. 151-152) 
- Blue opal from Peru and cat's-eye opal (Gem News: Summer 1991, pp. 120-121; Summer 1998, pp. 138-140)

Gaspeite from Australia was widespread and referred to as such; this was a departure from when we first saw this nickel carbonate reported as "Allura" (Summer 1994 Gem News, p. 125-126). Another unusual rare gem material that was far more common this year than previously was deep red eudialyte from Canada (Spring 1999 Gem News, pp. 49-50) and Russia.

\section{TREATMENTS}

Moonstone with dichroic backing. GIA Education product manager Wendi Mayerson saw some interesting stones at the booth of Gem Crafters, New York City. These moonstone (orthoclase feldspar) cabochons, sold as "Celestial moonstone," were backed with a very thin coating of a dichroic material. The coating produced moderate color in the stone, as well as a colored chatoyant band or cat's-eye. The five cabochons in figure 22 demonstrate the range of colors that were available; note that the gray cabochon somewhat resembles cat's-eye sillimanite. Natural cat's-eye moonstone of this quality, regardless of its bodycolor, exhibits a chatoyant band that is white. The different colors of the band in each of these stones provide an eye-visible indication of treatment or assembly, which could be easily confirmed by examining the underside of the stone.

According to information provided by the manufacturer, the backings on these samples are rather delicate, and should not be buffed, polished, exposed to abrasive jewelry cleaner, or cleaned using ultrasonic devices.

Figure 22. These five cabochons demonstrate the range of colors available in "Celestial moonstone," that is, moonstone backed with a dichroic film. They range from 5.90-6.10 3.85 $\mathrm{mm}$ to $7.90-8.00 \times 4.05 \mathrm{~mm}$; their total weight is $5.91 \mathrm{ct}$. Photo by Maha Tannous.

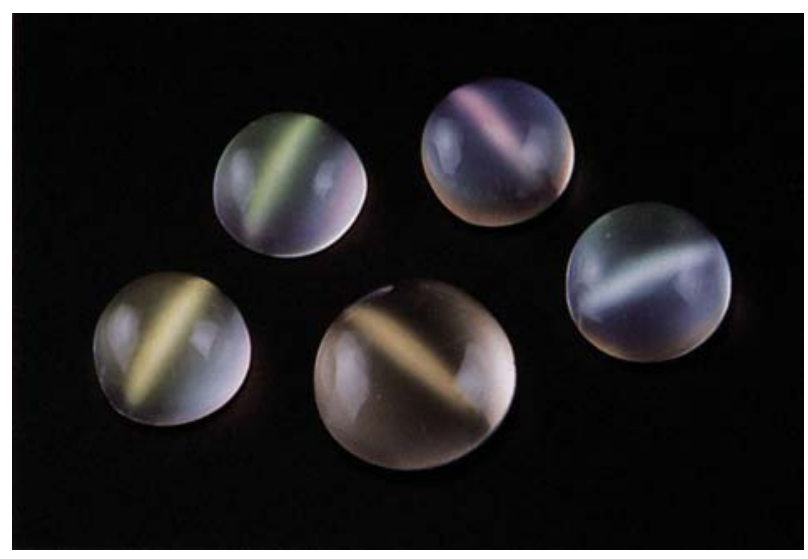

Instead, special care should be taken to clean the metal before mounting these items, and the stones should be cleaned with water and blotted dry. Hundreds of these cabochons were available at Tucson, in calibrated sizes.

Wendi Mayerson and $M L J$

New hues of dyed freshwater cultured pearls. Enormous quantities of freshwater cultured pearls flooded Tucson again this year, and a variety of treated colors were available. New colors included bright yellowish green, "golden" green, and various shades of blue-from light violetish blue (figure 23) through intense "royal" blue. This year, many dealers were calling their strands "heated," although most strands displayed colors that obviously were irradiated or dyed (including pink, green, and blue). As certain dyes may require heat to be activated or set, the term may refer to a heated dye bath; more information is needed about the "heating" process.

Cheryl Wentzell

Heat-treated rubies: Glass or not glass? One of the important issues at Tucson this year was that of the nature of the "fillings" in heat-treated rubies. A major concern was the potential for misidentification of a natural surfacereaching inclusion as foreign material (see, e.g., J. L. Emmett, "Fluxes and the heat treatment of ruby and sapphire," Fall 1999 Gems Æ Gemology, pp. 90-92). Kenneth Scarratt provided the following information.

Since 1984, laboratories and gemologists have been identifying the substances in cavities within ruby and sapphire as "glass" based on visual appearance (surface luster, bubbles, evidence of devitrification, etc.; see, e.g., R. R. Harding and K. Scarratt, "Glass infilling of cavities in natural ruby," October 1984 Journal of Gemmology, pp. 293-297; R. E. Kane, "Natural rubies with glass filled cavities," Winter 1984 Gems e) Gemology, pp. 187-199|. 


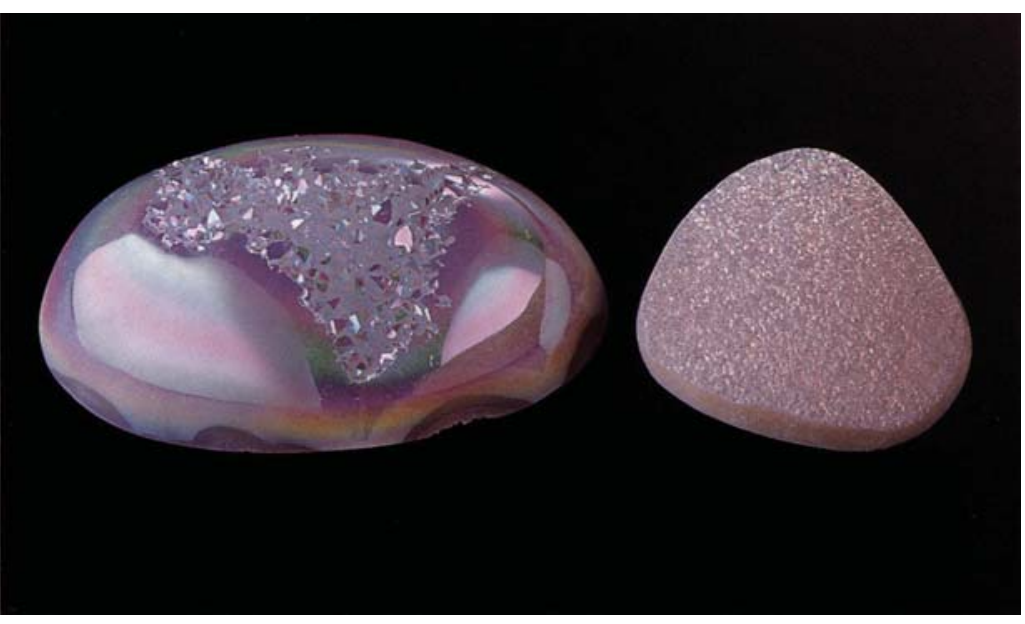

Figure 24. This $86.21 \mathrm{ct}$ white quartz geode (left) from Rio Grande do Sul, Brazil, owes its pearlescent surface and iridescence to a sputtered coat of silicon. The same coating on white drusy calcite specimens, such as the $18.38 \mathrm{ct}$ piece from Romania on the right, created a sparkling off-white pearlescent effect. Courtesy of Rare Earth Mining Co.; photo by Maha Tannous.

Sophisticated techniques have not been used routinely, because of the high cost of advanced testing and the fact that (until relatively recently) the quantity of rubies with glass-filled cavities has not been large.

It has become normal practice in Bangkok to use hydrofluoric acid (a strong acid that dissolves silicates

Figure 25. This 43.24 ct hydrothermal synthetic morganite beryl was grown on a seed plate of synthetic emerald; the resulting color combination resembled bicolored tourmaline. Courtesy of Tom Chatham, Chatham Created Gems; photo by Maha Tannous.

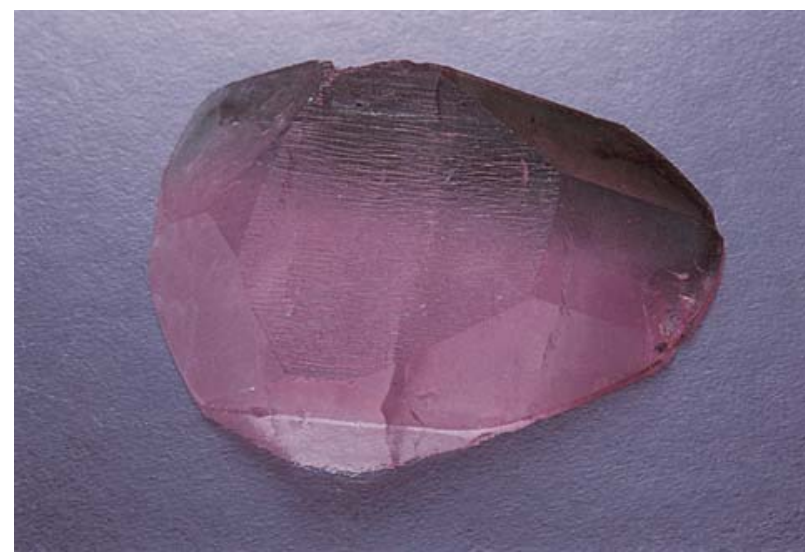

easily and which must be handled with great care) to "clean" rubies of any glass remaining on the surface following heat treatment. This is done either by the company that has treated the rubies or later by gem laboratories as an additional service to clients. (The normal technique for the removal of glass in cavities requires that the ruby be immersed in hydrofluoric acid for just a few seconds or minutes.) Within the last few years, this author has experienced several situations where what appeared to be glass within a cavity in ruby could not be removed with hydrofluoric acid. Although these materials had all the visual characteristics of glass fillings, the fact that they could not be removed in the normal manner left their identity open to question.

As a result, over the past several months the AGTA Gemological Testing Center in New York has introduced a policy of recording the Raman spectra of all "glass appearing" substances within cavities in rubies that are submitted for examination. This has been made possible only because of the greatly simplified operation of the latest models of laser Raman microspectrometers compared with earlier versions. In the course of implementing this policy, staff members at the Gemological Testing Center have discovered several fillings that appeared to be glass when examined with magnification but actually were not silicate glass. In one instance, a cavity had a level plateau of a transparent substance (slightly undulating and of melted, glass-like appearance) just below the surface of the stone. Raman analysis proved that this substance was in fact corundum with a small area of anatase (a titanium oxide mineral). Both corundum and anatase have sharp peaks at characteristic wavenumbers in their Raman spectra, whereas the glass typically encountered in ruby cavities does not. This example illustrates that care should be taken in identifying what appear to be foreign substances within cavities in ruby.

Kenneth Scarratt AGTA Gemological Testing Center New York, NY

Silicon coating of drusy materials. There was a continued abundance of fashioned drusy material at Tucson. In addition to titanium-coated drusy cabochons (see, e.g., Summer 1998 Gem News, pp. 142-143), we saw siliconcoated samples at the booth of Bill Heher, Rare Earth Mining Co. By means of vapor deposition (cathode sputtering), silicon was used to coat white drusy Brazilian agate, which was then repolished. The resulting pearlescent white specimens displayed strong iridescence (figure 24). Silicon also was used to coat white drusy calcite from Romania, with smaller crystals than the quartz mentioned above, creating sparkling off-white pearlescent specimens. According to Mr. Heher, only a "pure" white host material produced usable specimens.

Cheryl Wentzell and Sam Muhlmeister 


\section{SYNTHETICS AND SIMULANTS}

Bicolored synthetic beryl, resembling tourmaline. Tom Chatham of Chatham Created Gems, San Francisco, California, showed us about half a dozen samples of hydrothermal synthetic beryl (see, e.g., figure 25), which his company and Biron of Australia had grown on an experimental basis. For this experiment, they grew synthetic morganite on seed plates of synthetic emerald. When viewed along the seed plate, the color zones formed by the green seed plate and the pink overgrowth were sharp and distinct. Although this material was not a commercial product, it was notable for its interesting appearance, which caused several experienced gemologists to guess at first glance that it was pink-and-green bicolored tourmaline. Of course, no gem-quality synthetic tourmaline has appeared as yet on the market.

\section{MISCELLANEOUS}

"Floating diamonds" in jewelry. Graduate Gemologist and jewelry designer Georges Mouzannar, of Joaillerie Georges J. Mouzannar in Kaslik, Lebanon, showed senior staff gemologist Maha Tannous the "floating diamond" line, a collection of $18 \mathrm{~K}$ white gold jewelry (rings, earrings, and pendants) that features diamonds set in a colorless resin. At first glance, even to an experienced jeweler/gemologist, the diamonds appear to be suspended in mid-air.

The soft resin is cast and hardened by slow, controlled heating in a vacuum to avoid the formation of bubbles. Once hardened, the resin is filed and polished to a high luster. The setting area is etched into the hard resin, and the diamonds are then carefully inserted, with the assistance of a microscope, individually or in arranged

Figure 26. Seven 0.02 ct diamonds have been geometrically set in resin in this $18 \mathrm{~K}$ white gold ring. Photo by Maha Tannous.

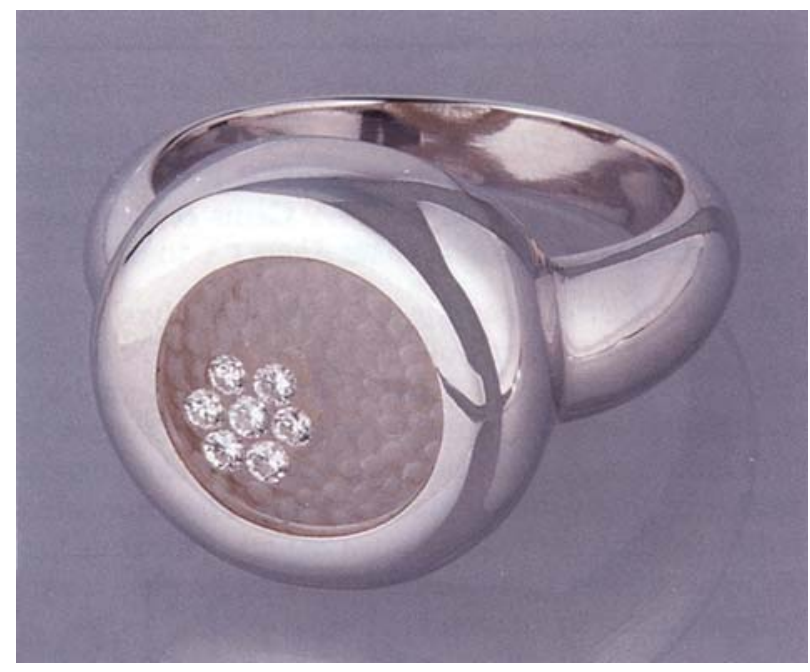

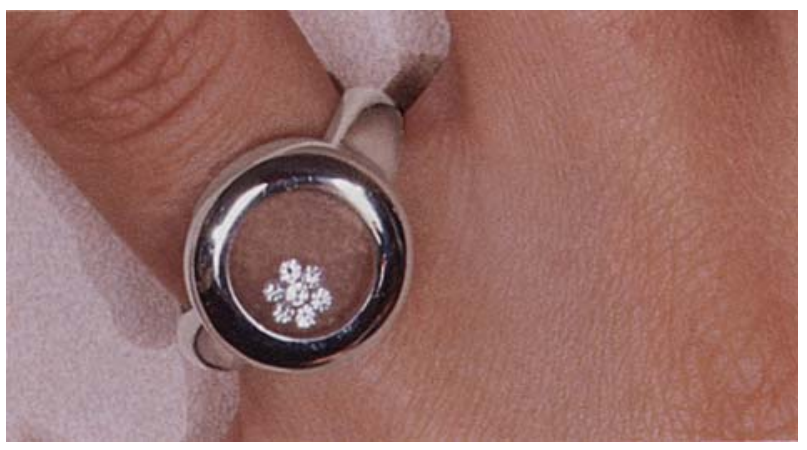

Figure 27. The resin evident in figure 26 is transparent against the skin, which causes the diamonds to appear as if they are floating in air. Photo by Maha Tannous.

geometric groupings (figure 26). The table facet of each diamond is leveled precisely with the surface of the resin so that all of the stones are in the same plane as that surface. The resulting setting is transparent when worn against the skin (figure 27), so the resin-set diamonds appear to be free-floating. Although we know of no systematic durability tests that have been conducted, the line appears to have withstood the hardships of daily wear, including exposure to sunlight and saltwater, since it was introduced in Lebanon well over a year ago.

Maha Tannous

Bismuth egg. Among the most fabulous objets d'art are the Easter eggs created at the turn of the last century for the Romanoff court by Peter Carl Fabergé and his atelier. Since then, gem-set eggs or those carved from ornamental materials continue to be popular. We saw a unique variation on these objects in the room of Gunnar Färber, Swamswegen, Germany, at the Executive Inn in Tucson this year. Crystal grower Udo J. A. Behner of Wadern, Germany, crystallizes bismuth in chicken eggshells (figure 28); the resulting eggs contain miniature scenes of iridescent tarnished skeletal bismuth crystals.

\section{ANNOUNCEMENTS}

GIA on the Internet. Gems $\oplus$ Gemology is pleased to announce the new design and format of the GIA Web site, www.gia.edu. In addition to its new look and easier navigation, the site features expanded content, including news and events under "Today at GIA." During your visit to the GIA site, be sure to click on Gems $\oplus$ Gemology. Our online version now contains a weekly news update, with more features and links on the way.

Faceters' Symposium 2000. Presented by the Faceters' Guild of Southern California, this year's Faceters' Symposium will take place August 4-6 at the Riverside 


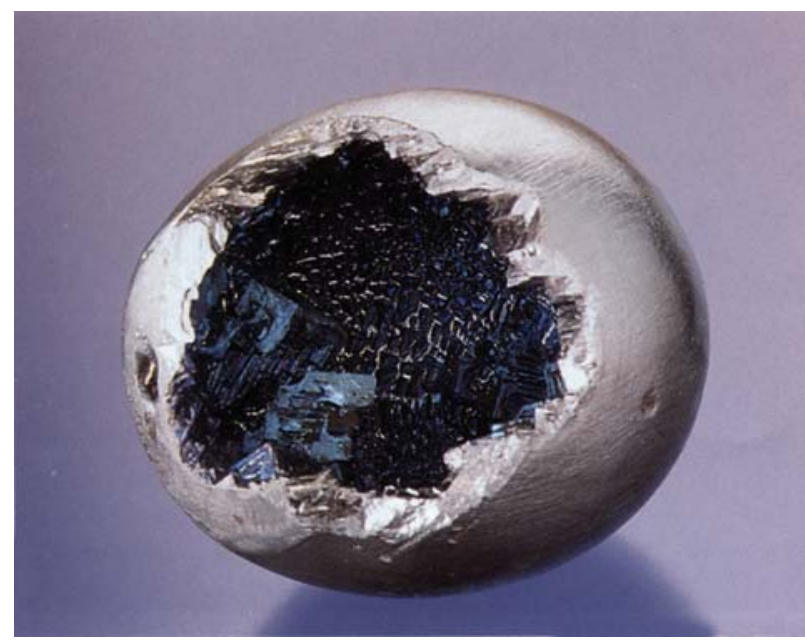

Figure 28. This $43.0 \times 37.4 \times 37.0 \mathrm{~mm}$ hollow bismuth egg contains a crystalline scene inside. Photo by Maha Tannous.

Convention Center. The Symposium, which is being held in conjunction with the California Federation of Mineralogical Societies Gold \& Gem Show, will feature speaker presentations on a number of topics that pertain to faceting. Cutting demonstrations, displays of faceted gemstones as well as faceting equipment, and faceting competitions (Novice through Masters) also will be offered. For more information or to register, contact Glenn Klein at 949-458-5803 (phone), or glennklein@yahoo.com (e-mail).

GANA exhibit in Los Angeles. An exhibition of selected gemstone artworks by members of Gem Artists of North America (GANA) will be on display at the Los Angeles County Museum of Natural History's Hall of Gems and Minerals from May 4-July 30, 2000. Among the works that will be on display is "Bahia," a rutilated quartz crystal from Bahía, Brazil, carved by Glenn Lehrer and

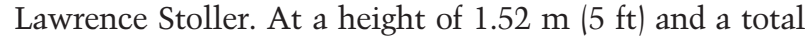
weight of $273.3 \mathrm{~kg}$ (602 lbs), it is the world's largest transparent gem carving. For information on the exhibit, contact the museum at 213-763-3466 (phone), or visit the Web site www.nhm.org/minsci.

Jewelry 2000. The 21st annual Antique \& Period Jewelry and Gemstone Conference will take place July 29-August 2 at Bryant College in Smithfield, Rhode Island. Formerly held at the University of Maine at Orono, this conference offers a curriculum of lectures and hands-on seminars conducted by leading gem experts, curators, auction representatives, dealers, appraisers, and designers. "Jump Start," a pre-conference program designed to reinforce basic jewelry skills and concepts, will be held July 27-29. For more details, contact the conference at 212-535-2479 (phone), 212-988-0721 (fax), or visit the Web site www.jonas4jewelry.com.

Tourmaline 2000. This exhibition is ongoing at the German Gemstone Museum in Idar-Oberstein, until August 27, 2000. The exhibit features more than 500 pieces (mostly from private collections in IdarOberstein), including crystals, carvings, cabochons, faceted stones, and slabs. Contact Dr. Joachim Zang at 49-6781-33210 (phone), 49-6781-35958 (fax), or Joachim.Zang@T-Online.de (e-mail).

Gemstones at upcoming scientific meetings. These upcoming meetings will feature sections on gemstones:

- Lectures on the geology and mineralogy of the Argyle diamond mine and Australia's opal fields will occur at the Australia's Greatest Mineral Deposits conference on June 10-12, 2000, in Broken Hill, New South Wales. The meeting is presented by the Mineralogical Society of New South Wales, 02-9685-9977 (phone), 029685-9915 (fax), or p.williams@uws.edu.au (e-mail).

- Gemological collections in museums and problems of gemology are among the topics that will be covered at the Mineralogical Museums in the 21st Century meeting in St. Petersburg, Russia, June 26-30, 2000. For more information, call 7-812-328-9481 or e-mail dept@mineral.geol.pu.ru.

- Australian Gemstones will be one of the topics at the 15th Australian Geological Convention in Sydney, July 3-7, 2000. A pre-meeting field trip (June 27-July 1) will include a visit to volcanic-associated sapphire deposits. For details, contact the Convention Secretariat at 61-29411-4666 (phone) or 61-2-9411-4243 (fax), or visit the web site www.science.uts.edu.au/agc/agchome.html.

- A special session on gems will take place at the 6th International Congress on Applied Mineralogy (ICAM 2000) in Göttingen, Germany, July 13-21, 2000. To learn more, call 49-511-643-2298, fax 49-511-643-3685, e-mail icam2000@bgr.de, or log on to www.bgr.de/icam 2000.

\section{ERRATA}

1. Mary Shore of Denver, Colorado, was omitted from the 1999 Challenge Winners (Summer 1999, p. 135) despite scoring a perfect $100 \%$ on the 1999 Gems \& Gemology Challenge. Congratulations to Ms. Shore.

2. In a recent letter regarding the Seifert and Hyrsl article "Sapphire and Garnet from Kalalani, Tanga Province, Tanzania" (Summer 1999 issue of Gems \& Gemology, pp. 108-120), Cedric Simonet and Silvant Okundi of Rockland Kenya Ltd. pointed out that the correct spelling of the word malaia is malaya. They indicated that in Swahili, the word malaya means "prostitute"; it was applied to this gem variety of garnet because it was formerly mistaken for sapphire. 